\title{
Daily activity patterns and occurrence of Leopardus guttulus (Carnivora, Felidae) in Lami Biological Reserve, southern Brazil
}

\author{
Paloma Linck ${ }^{1,2}$ (1) , Flávia P.Tirelli2,3 (D), Maria Carmen Bastos ${ }^{4}$ (D), Anderson N. Fonseca ${ }^{4,5}$ (D), \\ Liliana F. Cardoso 4 (D) \& Tatiane C. Trigo 1,3 (D)
}

\author{
1. Setor de Mastozoologia, Museu de Ciências Naturais do Rio Grande do Sul, Secretaria Estadual de Meio Ambiente e Infraestrutura (SEMA-RS), Porto Alegre, RS, Brazil. \\ (tatiane.trigo@gmail.com; paloma.linck@ua.pt) \\ 2. Laboratório de Evolução, Sistemática e Ecologia de Aves e Mamíferos, Programa de Pós-Gradução em Biologia Animal, Instituto Biociências, \\ Universidade Federal do Rio Grande do Sul (UFRGS), Porto Alegre, RS, Brazil. (flavia.tirelli@gmail.com) \\ 3. Instituto Pró-Carnívoros, Atibaia, SP, Brazil. (flavia.tirelli@gmail.com;tatiane.trigo@gmail.com) \\ 4. Reserva Biológica do Lami José Lutzenberger, Porto Alegre, RS, Brazil. (mcarmen@smam.prefpoa.com.br; lilianafssc@yahoo.com.br) \\ 5. Universidade Luterana do Brasil (ULBRA), Canoas, RS, Brazil. (ander.vn@gmail.com)
}

Published 29 March 2021

DOI 10.1590/1678-4766e2021006

ABSTRACT. Daily activity patterns are important elements of species behavior that reflect how they interact with their environment and with other related species. To investigate these patterns is crucial to understand how environmental or community changes may affect this behavior in each particular species. Within the Felidae family, research becomes fundamental to assess how small wild cats respond to local conditions and pressures, once there is a large gap in studies addressing such issues. Leopardus guttulus (Hensel, 1872) is an endangered species classified as Vulnerable (VU) at a regional and global level, being threatened mainly by the loss and fragmentation of its habitats. The aim of this study is to document the daily activity patterns of L. guttulus at the Lami Biological Reserve, and the influence of seasonality and temperature on those patterns. We also aimed to quantify how many individuals were using the Biological Reserve during the study period and evaluate their permanence in the area. We obtained 25 independent records for L. guttulus, which was the only cat species recorded at the site during the study period. In general, the species presented a cathemeral habit, being active throughout the 24 hours of the day, but with a more crepuscular/nocturnal activity in the spring and summer. The relationship between the species' activity and temperature showed that more than $70 \%$ of the records were obtained in a narrow range of $10-17^{\circ} \mathrm{C}$. We identified at least two individuals that remained at the site from four to six months of the year, with a higher detection frequency between August and November. Our results showed some interesting trends for the temporal activity of L. guttulus, suggesting flexibility related to seasonality, and the importance of the biological reserve to the preservation of this cat species in the southern limit of its distribution.

KEYWORDS. Camera trap, circadian activity, Neotropical felids, southern tiger cat, protected area.

RESUMO. Padrões de atividade diária e ocorrência de Leopardus guttulus (Carnivora, Felidae) na Reserva Biológica do Lami, sul do Brasil. Os padrões de atividade diária são elementos importantes do comportamento das espécies que refletem como elas interagem com seu ambiente e com outras espécies relacionadas. Investigar esses padrões é crucial para entender como as mudanças ambientais ou na comunidade podem afetar esse comportamento em cada espécie em particular. Dentro da família Felidae, os felinos silvestres de menor porte sofrem com uma grande lacuna de estudos nesse sentido, e pesquisas se tornam fundamentais para avaliar como eles respondem às condições e pressões locais. Leopardus guttulus (Hensel, 1872) é uma espécie ameaçada de extinção classificada como Vulnerável (VU) em nível regional e mundial, sendo ameaçada principalmente pela perda e fragmentação de seus habitats. O objetivo deste estudo é documentar o padrão de atividade diária de L. guttulus na Reserva Biológica do Lami e verificar a influência da sazonalidade e da temperatura nestes padrões. Nós também tentamos identificar o número de indivíduos usando a reserva biológica durante o período monitorado e avaliar o tempo de permanência destes na área. Obtivemos 25 registros independentes para L. guttulus, sendo a única espécie de felídeo silvestre registrada no local durante o período amostrado. No geral a espécie apresentou um hábito catemeral com atividade ao longo das 24 horas do dia, mas com uma maior atividade crepuscular/noturna nas estações da primavera e verão. A relação entre a atividade da espécie e a temperatura mostrou que mais de $70 \%$ dos registros foram obtidos em uma estreita faixa de temperatura de $10-17^{\circ} \mathrm{C}$. Nós identificamos pelo menos dois indivíduos que permaneceram no local durante quatro a seis meses no ano, com maior frequência de detecção nos meses entre agosto e novembro. Nossos resultados demonstram algumas tendências interessantes sobre a atividade temporal de L. guttulus, sugerindo uma flexibilidade sazonal, e demonstram também a importância da reserva biológica para a preservação desta espécie no limite sul de sua distribuição.

PALAVRAS-CHAVE. Armadilhagem fotográfica, atividade circadiana, felídeos neotropicais, gato-do-mato-pequeno-do-sul, áreas protegidas.

The investigation of species activity patterns gives us a better understanding of how the environment is exploited by each species and how the activity can be affected by different environmental or community changes (KERR, 1997). Among the mammals of the Carnivora order it is known that the activity pattern may be influenced by climatic factors such as temperature and seasonality (PODOLSKI et al., 2013; TORRETTA et al., 2016; ZHAO et al., 2020), availability and activity of the main prey species (FOSTER et al., 2013), anthropogenic interference (KolowsKI \& ALONso, 2010; Nix et al., 2018) 
and interaction with other carnivorous species to avoid intraguild competition and predation (ROMERO-MUÑOz et al., 2010; OliveIRA-SANTOS et al., 2012; FosTER et al., 2013).

Within the Felidae family, the temporal activity patterns of large species have been widely studied (e.g., HARMSEN et al., 2009, 2011; Foster et al., 2013; BALME et al., 2019; RAFIQ et al., 2020). Some of these studies have demonstrated the existence of different patterns among large felids with species-specific alterations in response to different factors, such as human presence (GAYNOR et al., 2018), seasonality (PoDOLSKI et al., 2013), and the presence of prey and/or competitors in the environment (FOSTER et al., 2013). In contrast, such temporal activity patterns are not available for many species of smaller cats $(<10 \mathrm{~kg})$ due to the lack of studies (MACDONALD \& Loveridge, 2010). Therefore, researches become important to identify the patterns observed in these species and to evaluate how they respond to local conditions and pressures.

Leopardus guttulus (Hensel, 1872), the southern tiger cat, was recently recognized as a distinct taxon from Leopardus tigrinus (Schreber, 1775), the northern tiger cat [or L. emiliae (Thomas, 1914) according to NASCiMENTO \& FeIJó, 2017] based on molecular (Trigo et al., 2013a) and morphological evidences (NASCIMENTo \& FeiJó, 2017). The two species present basically disjunct geographical distributions, once Leopardus guttulus is restricted to the South, Southeast and Central-West regions of Brazil, as well as Paraguay and northeastern Argentina, whereas the occurrence of L. tigrinus probably extends from central and northeastern Brazil in South America to Central America (Trigo et al., 2013a; OliveIra et al., 2016). At the State of Rio Grande do Sul (Brazil), L. guttulus is limited to the northern portion, with the transition zone between the Atlantic Forest and the Pampa biomes constituting the southern limit of its distribution (EIZIRIK et al., 2006). This is considered an endangered species, being classified as Vulnerable (VU) at Rio Grande do Sul (Estado do Rio Grande do Sul, 2014), Brazil (MinistÉrio do MeIo AmbiENTE, 2018) and globally (OLIVEIRA et al., 2016). It is associated mainly with the forested environments of the Atlantic Forest, being threatened mostly by the loss and fragmentation of its habitats caused by the expansion of human activities (e.g., agriculture, livestock, urban sprawl, etc.). It also suffers from illegal hunting, conflicts with humans, competition and/or predation by domestic carnivores (dogs and cats), and even road killings (OliveIRA et al., 2016).

In recent years, some studies including the evaluation of this species' daily activity patterns have been conducted in other Brazilian's states, such as ToRtato \& Oliveira (2005) and Oliveira-SAntos et al. (2012) in Santa Catarina, Massara et al. (2016) in Minas Gerais, Nagy-Reis et al. (2019) in São Paulo; and also in other countries, such as DI BitetTr et al. (2010) and CRUZ et al. (2018) in Argentina. Overall, these studies have indicated that the species presents a more nocturnal activity in locations with higher human access, and a more cathemeral pattern when it co-occurs with other cats such as ocelots, margays or pumas. Nevertheless, in areas bordering the species' distribution, such as the State of Rio Grande do Sul, there is still no information available regarding its behavior. Therefore, the main objective of this study is to document and to evaluate the daily activity patterns and occurrence of L. guttulus at the Biological Reserve Lami José Lutzenberger, inserted in the southern limit of the species' distribution. We evaluated these patterns over a period of approximately one year of monitoring. Considering the available data on literature for this species, we expected a more cathemeral activity in the study area, since protected areas should show a lower disturbance due to human presence, and because we expected to document the presence of other wild cat species, such as Leopardus wiedii (margay) (TRIGO et al., 2013b). Because we monitored the area through a long period, we also tried to verify the influence of seasonality and temperature on the activity of this species, since other studies have shown that these climatic conditions could also trigger some changes on the activity of some mammal species (TORRETTA et al., 2016; LEONARD et al., 2020). Finally, we evaluated the distribution of the occurrence records during the monitored period and tried to identify how many individuals used the study area, and how long they stayed within the limits of the Biological Reserve.

\section{MATERIALS AND METHODS}

Study area. The Biological Reserve Lami José Lutzenberger (BRLJL) is located at the State of Rio Grande do Sul (RS), southern Brazil. It is inserted in a rural matrix within the city of Porto Alegre ( $\left.30^{\circ} 14^{\prime} 08^{\prime \prime} \mathrm{S}, 51^{\circ} 05^{\prime} 42^{\prime \prime} \mathrm{W}\right)$, and is close to several urban centers (Fig. 1). With an area of 204.04 hectares, this is a small but important protected area located at the margins of the Guaíba Lake (PRINTES, 2002). BRLJL is inserted in the transition zone of the two biomes present in RS, the Atlantic Forest and the Pampa. The area is covered mainly by wetlands and Restinga forest formations, being the latter recognized as a rare and seriously threatened ecosystem at RS (PRINTES, 2002). In this region, mean temperatures ranges from $26^{\circ} \mathrm{C}$ in January (summer) to $15^{\circ} \mathrm{C}$ in June (winter), and the mean precipitation varies from 95 millimeters in the driest months (November-May) to 130 millimeters in the rainiest months (June-October) (INMET, 2018).

Camera trapping. BRLJL was monitored with camera trapping from July 2018 to June 2019. We subdivided the area into $1 \times 1 \mathrm{~km}$ grid squares and selected four of them to monitor through camera traps, considering the small size of the protected area, the available number of cameras $(n=4)$ and the conditions of access to certain areas (Fig. 1). At each of these squares we installed one camera (Bushnell TrophyCam), representing our sampling station, and maintained a minimum distance of $1 \mathrm{~km}$ between adjacent sampling stations. This distance was defined based on the diameter of the minimum home range $\left(<1 \mathrm{~km}^{2}\right)$ described for a female of the species (OliveIra et al., 2010), and was also used in similar studies conducted by our research group (e.g., HorN et al., 2020). 


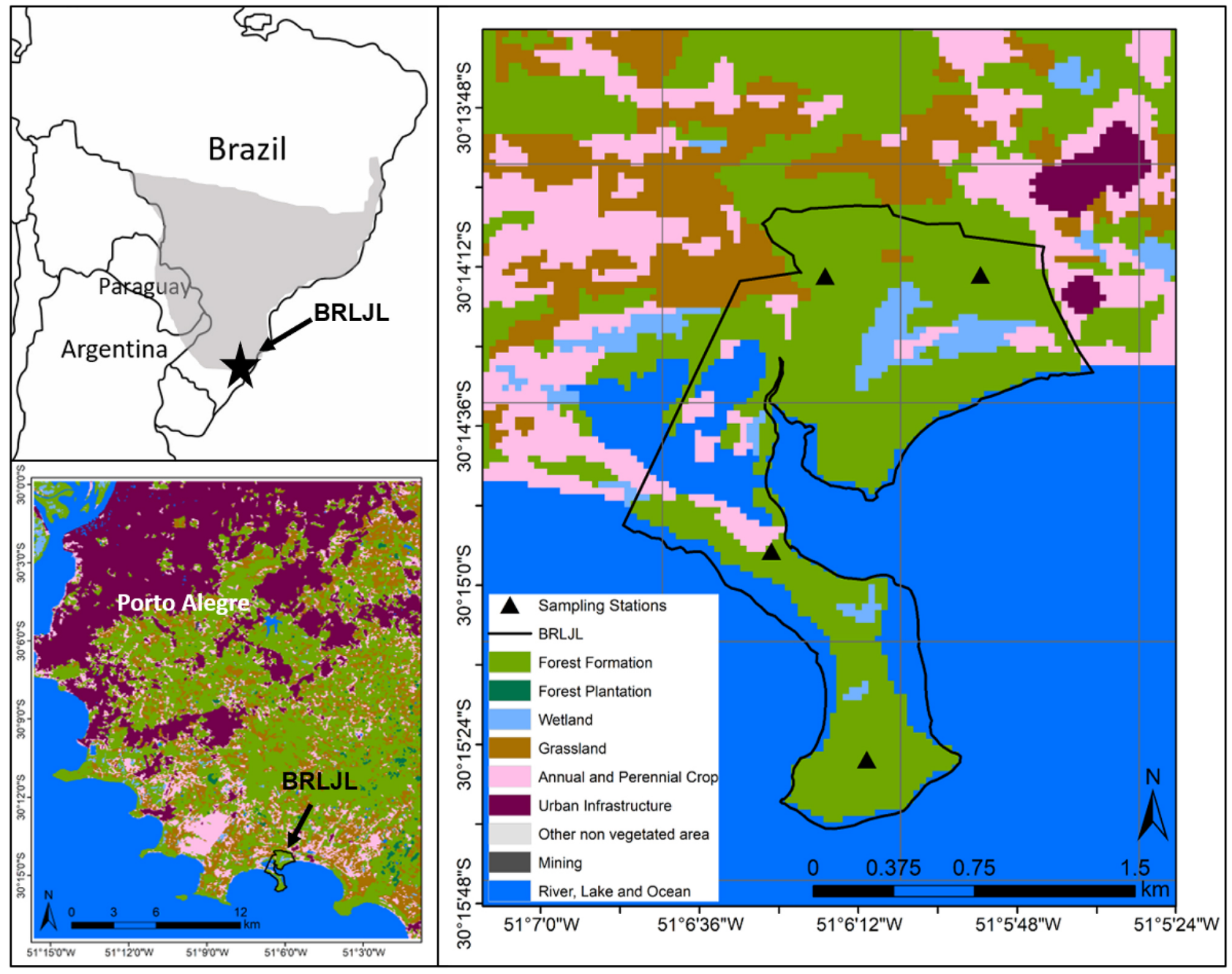

Fig. 1. Location of the study area in South America and the State of Rio Grande do Sul (left panel), with the indication of the geographic range of Leopardus guttulus (Hensel, 1872) (grey area) in Brazil, Paraguay and Argentina (above), and the Biological Reserve Lami José Lutzenberger - BRLJL in the municipality of Porto Alegre, Rio Grande do Sul, Brazil (below). On the right panel, a detailed map of the study area showing the limits of the BRLJL (black line), the vegetation types occurring in the area, the grid squares of 1 x $1 \mathrm{~km}$ (grey lines) designed to delimitate the zones where sampling stations (camera stations) were installed (black triangles).

Cameras were revised every 30 days to check equipment operation and to change batteries and memory cards. On these monthly reviews, some cameras were moved to new points inside the same sampling square but always maintaining the $1 \mathrm{~km}$ distance between the cameras of adjacent stations. Camera traps were fixed to trees about 30 $\mathrm{cm}$ from the ground, in trails or near places where evidences of wild mammals were found (e.g., footprints, feces and wildlife trails). Cameras were programmed for photo capture (night recording with infrared function) and were active 24 hours a day without the use of baits. The records obtained have information on temperature, date and time of capture. All felid records were separated and identified. Only records obtained with at least one hour from each other, at the same sampling station, were included in the analysis and were depicted as independent records. This was carried out in order to reduce the chance of capturing consecutive records of the same individual and thus maintain temporal independence between records, avoiding autocorrelation (FOSTER et al., 2013; Porfirio et al., 2016; Horn et al., 2020). Records obtained in a shorter interval in the same sampling station were only considered if we could identify that it is related to a different individual, according to its pelage patterns.

Species identification was based on the general pelage patterns and other specific characteristics. For the area comprising the Biological Reserve, besides Leopardus guttulus, at least two others species of wild cats are expected to occur: Leopardus wiedii (margay) and Herpailurus yagouaroundi (jaguarundi) (TRIGO et al., 2013b). The second species is easy to recognize since it presents uniform pelage coloration. On the other hand, L. guttulus and $L$. wiedii are similar in body size and both present a spotted pelage pattern. Distinction between them is based mainly on differences of the spotted pattern, tail length, and eyes and paw shapes as described in Oliveira \& CASSARo (2005). As we used only one camera trap per site, individual identification was 
performed based on their unique spot patterns using only the records obtained for the same side of the animal's flank (left or right, the one with the largest number of records).

Data analyses. To investigate the daily activity pattern of $L$. guttulus at the BRLJL, we first used the circular statistic, with the Rayleigh Uniformity Test in "circular" package version 0.3-5 (AGOSTINELLI \& LUND, 2017) in the R software (R CORE TEAM 2020) to test the data for a uniform or nonuniform distribution of the records throughout the 24 hours of the day (MARDIA \& JUPP, 2000). A significant value for the Rayleigh's Test indicates a non-uniform distribution (with records concentrated in a specific period of the day), while a non-significant value indicates that there is not enough evidence to reject the null hypothesis of uniformity, and the activity may be occurring during the 24 hours of the day with no specific peak of activity in a cathemeral pattern. We performed this analysis for the entire sample, as well as for the data subdivided into two subgroups related to the different seasons of the year: autumn/winter $\left(20^{\text {th }}\right.$ March $-21^{\text {st }}$ September) and spring/summer $\left(22^{\text {nd }}\right.$ September $19^{\text {th }}$ March), in order to verify if the species modifies its predominant activity according to climatic characteristics. In this same analysis we also evaluated the angular mean $(\mu)$ and length of the mean vector $(r)$ as an indicative of the level of concentration of the data. The length of the mean vector can vary from zero to one, with low values indicating a greater dispersion of the data around the mean and high values representing a greater concentration of the data close to the angular mean. Significant differences between observed activity patterns in each pair of seasons (autumn/winter and spring/summer) was assessed with the Watson's Two-Sample Test of Homogeneity $\left(\mathrm{U}^{2}\right)$ with the same package in $\mathrm{R}$ software.

We also estimated the similarity of the daily activity of the species between the seasons through the overlap coefficient (Dhat1, for samples $<50$ ) and calculated the confidence intervals (CI) through 1000 bootstraps with the “overlap" package version 0.3.3 (RIDOUT \& LINKIE, 2009) in the R software (R CORE TEAm, 2020). Values of Dhat1 close to 1 indicate high activity overlap and values near zero indicate low overlap. To classify the activity's overlap as low, moderate or high, we used the same criterion of MONTERROSO et al. (2014), with Dhat1 values $<0.5$ considered as low, $0.5<$ Dhat $1<0.75$ as moderate and Dhat $1>0.75$ as high activity overlap.

Finally, we classified the activity of L. guttulus in three categories: diurnal $(\geq 60 \%$ of the records obtained between 1 hour after sunrise and 1 hour before sunset), nocturnal ( $\geq 60 \%$ of records obtained 1 hour after sunset and 1 hour before sunrise) or crepuscular (at least $50 \%$ of records obtained in the interval of 1 hour after and before sunrise and sunset) (MASSARA et al., 2018; Dias et al., 2019). Times of sunrise and sunset were obtained from https:// sunrise-sunset.org/ for all days of the monitored period. We used these data to calculate the mean value of sunrise and sunset for the general data, as well as for the seasonal periods considered. Differences between seasons were assessed by chi-square test $\left(\chi^{2}\right)$. Finally, we evaluated the relationship of species activity to changes in temperature $\left({ }^{\circ} \mathrm{C}\right)$ in the environment, assessing the temperature registered in each independent record.

To investigate the patterns of $L$. guttulus occurrence in BRLJL, first we estimated the species' detection rate by the number of records per 100 trap-days. Then, we evaluated the distribution of the occurrence records over the months of the year in order to verify a trend or not for a higher detection rate on certain periods. This analysis was also conducted with "circular" package (AGostineLLI \& LUND, 2017) in the R software, using the Rao's Spacing Test to test the data for a uniform or non-uniform distribution. We also performed individual identification of the registered cats using their unique spot patterns, aiming to verify the number of individuals using the area during the monitored period and the time that each individual spent in the area.

\section{RESULTS}

We obtained 25 independent records for L. guttulus, and this was the only cat species recorded at the BRLJL throughout the sampled period. Due to the occurrence of equipment failures (e.g., battery discharge, system failure, stops on camera registering, etc.), the total sampling effort obtained was of 660 trap-days considering the number of days that each camera was active. The detection rate was 3.78 records per 100 trap-days.

Regarding the activity patterns of $L$. guttulus, when all records were analyzed together, no predominant activity was identified in any specific period of the day (Rayleigh's Test $=0.29, \mathrm{p}=0.12$ ) and a cathemeral habit was identified for the species, with a mean activity at 00:52 h (Fig. 2, Tab. I). Nevertheless, when considering the subdivision of the records in different seasons, autumn/winter and spring/summer, we identified differences between them. A cathemeral pattern (Rayleigh's Test $=0.0735, \mathrm{p}=0.9503$ ) was identified in autumn/winter $(\mathrm{n}=10)$ with a mean activity at $05: 00 \mathrm{~h}$, but at spring/summer $(\mathrm{n}=15)$, the activity was significantly concentrated in a specific period of the day (Rayleigh's Test $=0.4647, \mathrm{p}=0.0364$ ), with a mean activity at $00: 31 \mathrm{~h}$ (Fig. 2, Tab. I). As for the length of the mean vector, we had a much lower value for autumn/winter than for spring/summer, indicating a greater dispersion of records throughout the 24 hours of the day in the first pair of seasons and a greater concentration of records around the mean in the second one (Tab. I). In spite of this, the Watson's Two-Sample Test of Homogeneity $\left(\mathrm{U}^{2}\right)$ did not identify a significant difference between these two patterns $\left(U^{2}=0.0923, p>0.10\right)$.

Evaluating the temporal coefficient of overlap between the seasons we had an estimated value of Dhat $1=$ $0.56(0.36-0.83 \mathrm{CI})$, which is considered a moderate level of overlap. We could observe that the main differences between the two activity patterns were related to a higher intensity of activity during the day in autumn/winter and higher nocturnal activity in spring/summer (Fig. 3). If we look 
at the percentage of records of the three categories of daily activity considered here, the species could be classified as predominantly nocturnal only in spring/summer where $60 \%$ $(n=9)$ of records occurred during the night-time (Tab. II). In autumn/winter $40 \%(n=4)$ of records were nocturnal, while other $40 \%(n=4)$ occurred during the day. In contrast, only $13 \%(n=2)$ of the records in spring/summer were obtained in the diurnal period. In addition, the relationship of the species activity with the temperature showed that $72 \%(n=18)$ of the records were concentrated between $10^{\circ} \mathrm{C}$ and $17^{\circ} \mathrm{C}$ (Supplementary Material 1). Nevertheless, the chi-square test did not detect significant differences in the distribution of the records among the three categories and seasons $\left(\chi^{2}=\right.$ 2.3504, $\mathrm{gl}=2, \mathrm{p}=0.3088)$.
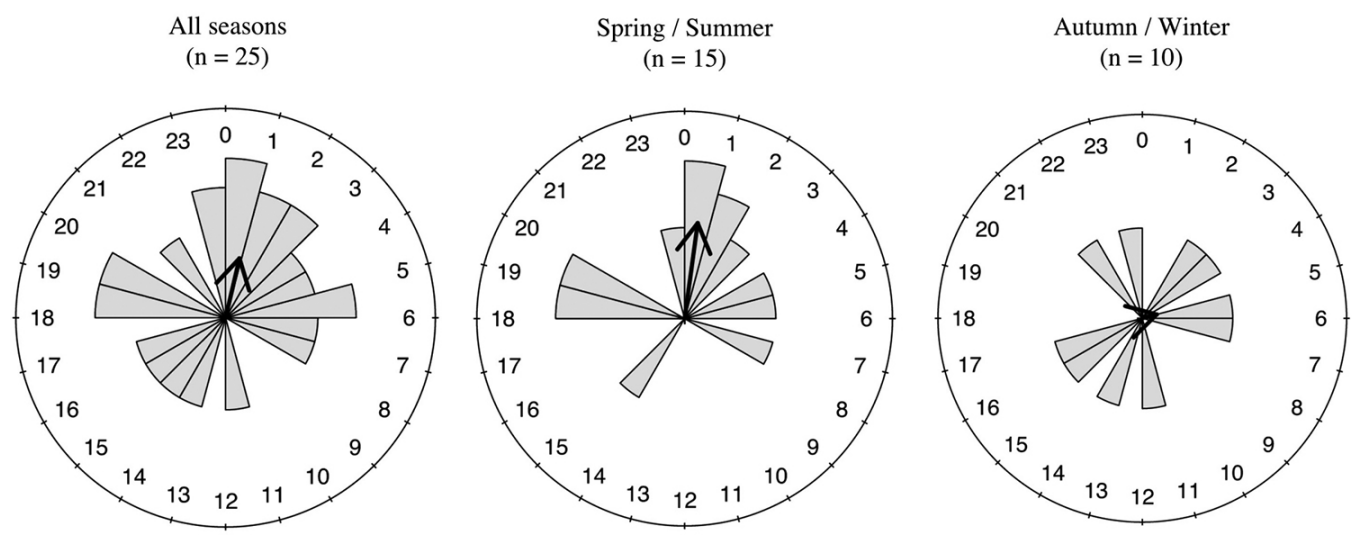

Fig. 2. Circular graphs showing the daily activity of Leopardus guttulus (Hensel, 1872) at the BRLJL, Rio Grande do Sul, Brazil, based on all records obtained for the species ( $\mathrm{n}=25$, all seasons), on records obtained during spring/summer $(\mathrm{n}=15)$, and on records from autumn/winter ( $\mathrm{n}=10)$. The arrow on each circular graphs indicates the direction of the angular mean.

Tab. I. Results from the circular analyses performed to investigate the daily activity of Leopardus guttulus (Hensel, 1872) at the Biological Reserve of Lami considering all records (all seasons), and also the two pairs of seasons (spring/summer and autumn/winter) separately.

\begin{tabular}{lcccc}
\hline & $\mathrm{n}$ & Length of the mean vector $(\mathrm{r})$ & Angular mean $(\mu)$ & Rayleigh's Test \\
\hline All seasons & 25 & 0.291 & $00: 52$ & 0.291 \\
Spring/Summer & 15 & 0.464 & $00: 31$ & $0.464^{*}$ \\
Autumn/Winter & 10 & 0.073 & $05: 00$ & 0.073 \\
\hline
\end{tabular}

$* \mathrm{p}<0.05$

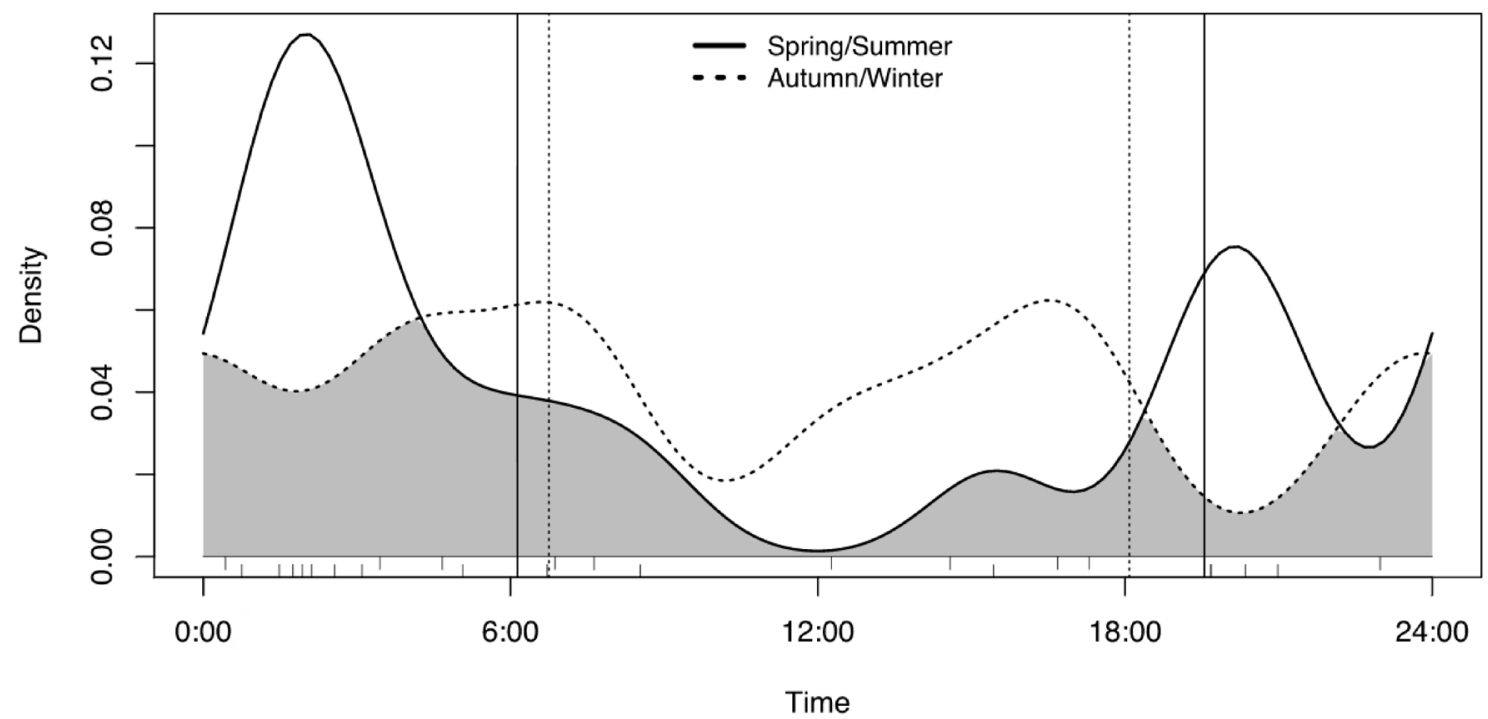

Fig. 3. Temporal overlap of Leopardus guttulus (Hensel, 1872) activity during the different seasons: autumn/winter and spring/summer; the gray area represents the overlap between the activity observed in the two periods of the year and the vertical lines represent sunrise and sunset in each period (autumn/winter: 06h 45min sunrise and 18h 05min sunset; spring/summer: 06h 08min sunrise and 19h 33min sunset). 
Regarding the occurrence patterns, the circular statistic showed a non-uniform distribution of the records throughout the monitored year (Rao's Spacing Test of Uniformity = $235.384, \mathrm{p}<0.001$ ), with a clear trend towards a greater detection rate between August and November (Fig. 4).We were able to confidently identify at least two individuals based on $60 \%$ of the records, including those obtained for the left flanks (the one with the higher number of records) with good quality photos for individual identification. Between the records individually identified, eight were from a female registered during the period of July 2018 to January 2019, and seven were attributed to a male registered seven times between August and November 2018 (Supplementary Material 2).

Tab. II. Percentage of records of Leopardus guttulus (Hensel, 1872) in each of the three categories of daily activity considering the general pattern (all records), and the patterns observed for each pair of seasons.

\begin{tabular}{cc}
\hline Activity categories & Records (\%) \\
\hline All records & \\
Diurnal & $6(24 \%)$ \\
Nocturnal & $13(52 \%)$ \\
Crepuscular & $6(24 \%)$ \\
Autumn/Winter & \\
Diurnal & $4(40 \%)$ \\
Nocturnal & $4(40 \%)$ \\
Crepuscular & $2(20 \%)$ \\
Spring/Summer & \\
Diurnal & $2(13.3 \%)$ \\
Nocturnal & $9(60 \%)$ \\
Crepuscular & $4(26.7 \%)$ \\
\hline
\end{tabular}

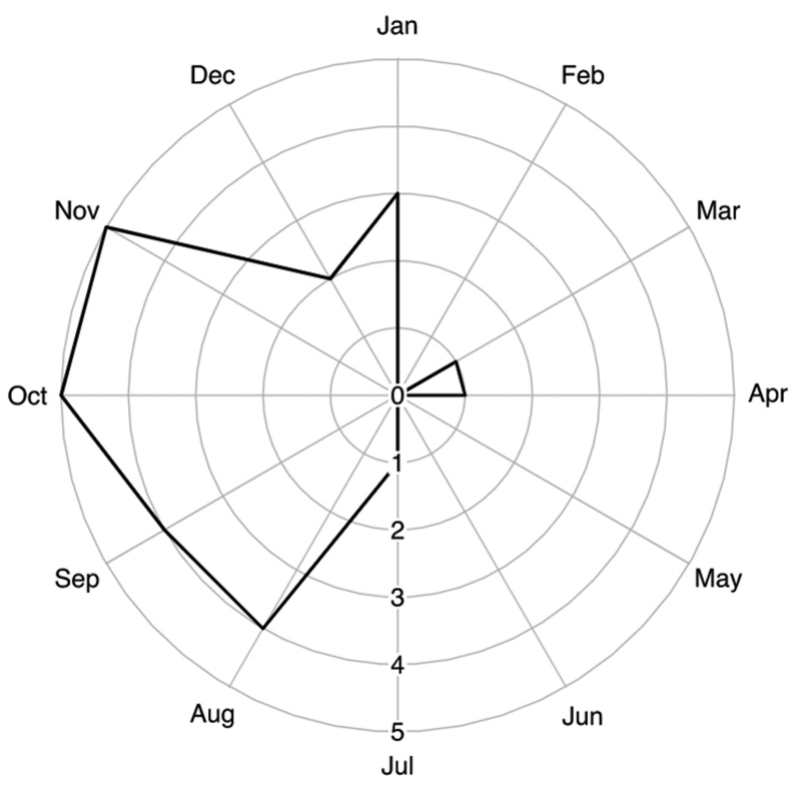

Fig. 4. Circular graph showing the distribution of Leopardus guttulus (Hensel, 1872) records in BRLJL, Rio Grande do Sul, Brazil, throughout the 12 months sampled. The black lines represent the concentration of records.

\section{DISCUSSION}

The one-year monitoring at the Lami Biological Reserve allowed us to identify an interesting pattern on the daily activity patterns of $L$. guttulus. According to our data, the species can adjust its behavior during the year probably to deal with higher temperatures in the warmer seasons. In addition, we identified at least two individuals using the area, with a higher number of records being detected in a specific period of the monitored period.

Flexibility in temporal activity of $L$. guttulus was already documented and was mainly attributed to human disturbance and presence of competitors (e.g., OliveIRASANTOS et al., 2012; Massara et al., 2016; CrUZ et al., 2018). In relation to human disturbance, in a study conducted in the Atlantic Forest of Argentina, Cruz et al. (2018) detected a more nocturnal activity for this species in locations with higher human access compared to more isolated sites, suggesting that these cats might be temporarily avoiding encounters with humans or dogs. Considering this, the conduction of the present study in a protected area made us expect a more cathemeral pattern of activity for this species since we expected a lower rate of human disturbance inside this area. This pattern was observed in the general analysis and in the colder seasons (autumn/winter), but not in the warmer seasons (spring/summer). In fact, despite being a protected area, the Lami Biological Reserve is a small reserve located near urban centers, which receives visitors throughout the year (M. C. Bastos, pers. observ.). In addition, during the monitored period we could observe a large number of dogs using the area or its boundaries. Therefore, we cannot exclude the possibility that human disturbance may have an important influence on the activity of $L$. guttulus also in this area, since we did not evaluate different intensity of human activity or dog's presence inside the Biological Reserve in different periods of the year. Only conducting specific analyses to assess these patterns one would be able to indicate more reliably if these factors have any influence on the activity patterns of $L$. guttulus also in this region.

In relation to the presence of other wild cats as competitors, some studies showed a cathemeral pattern for L. guttulus when in co-occurrence with other cats, as ocelots and margays (Di BitTeTI et al., 2010; OliveIRASANTOS et al., 2012; MASSARA et al., 2016; NAGY-ReIS et al., 2019), indicating that the species could develop this pattern of activity as a potential adjustment to reduce intraguild competition and avoid direct contact (e.g., competition for food, shelter, territory or agonistic meetings) with these cats through temporal segregation. While margays and ocelots seem to be more nocturnal species in several areas of their distribution (Di BitetTi et al., 2010; OliveIRA-SANTOS et al., 2012; MASSARA et al., 2016; CruZ et al., 2018; Horn et al., 2020), L. guttulus was observed as a nocturnal species only when it occurred with no other cats (OLIVEIRA-SANTOS et al., 2012). In our study area, L. guttulus was the only wild cat recorded throughout the monitored period, but the nocturnal activity was not the general pattern observed. Similarly, 
TORTATO \& Oliveira (2005) also found a more cathemeral activity for this species in an area of Restinga vegetation formations at the state of Santa Catarina, where no other cat species was recorded. Nevertheless, even if we not have registered another species of felid during a year of monitoring at the BRLJL area, we cannot exclude the possibility of the occurrence of other potential species such as the margay, which even in low abundance or density could have some effect on the activity patterns of $L$. guttulus.

At the BRLJL, L. guttulus maintained a predominantly nocturnal and crepuscular habit only during spring/summer, changing its period of activity to a cathemeral pattern with the arrival of autumn/winter. Nevertheless, the comparison between the two seasons was not statistically significant probably due to the amount of data obtained. Monitoring the area for a longer period (for example, two years or more) would probably generate a larger amount of data that could make statistical analyses more robust. Observing the graph showing the extent of niche overlap between the two evaluated periods, it is worth mentioning that the hours of the day, especially in the afternoon, seem to fall into disuse in the warmer seasons. It appears that $L$. guttulus can change its behavior in order to avoid diurnal activity during warmer periods, maintaining its foraging habits in periods when temperatures become milder.

Temperatures seem to be an important climatic variable to the occurrence of $L$. guttulus. According to SARTOR et al. (2021) this is one of the most important variables identified in suitability models for this species throughout its distribution, where areas with mean annual temperatures between $18-21^{\circ} \mathrm{C}$ show the highest occurrence probability for the species. Above these temperatures, the occurrence probability of $L$. guttulus decays dramatically (SARTOR et al., 2021). In this study, temporal activity was predominant in lower temperatures, with more than $70 \%$ of records concentrated between $10^{\circ} \mathrm{C}$ and $17^{\circ} \mathrm{C}$, also contributing to the recognition of the importance of temperature in the occurrence and activity of the species. The effects of seasonality and/ or temperature were also reported for other cat species. LEONARD et al. (2020) in a study at Southern Texas, observed that ocelots show a reduction of its daytime activity during the warmer days of the year and that bobcats (Lynx rufus) show a predominant crepuscular pattern during the winter and a nocturnal pattern in the spring. In the Eurasian linx (Lynx lynx), PODOLSKI et al. (2013) also document a decrease in the species' activity by 30 minutes for every $10^{\circ} \mathrm{C}$ of temperature increase.

The two activity patterns observed for L. guttulus throughout the year may also be a result of the adjustment of the predator activity in function of its prey. On warmer periods of the day, it is probable that there is also a reduction on the intensity of prey activity (MARINHO et al., 2018). Likewise, in colder seasons it is also expected a reduction of prey availability and so, in this period, a cathemeral habit would increase the likelihood of encountering a greater range of possible preys (CARRILLO et al., 2009; HERNÁNDEZSAINTMARTín et al., 2013). At the Caatinga biome, the northern tiger cat presents predominantly crepuscular and nocturnal habits that may be associated to water stress and temperature conditions of the daytime and the main activity period of the preys rather than regulation by intraguild predation or competition (PENIDO et al., 2017; MARINHO et al., 2018). These conditions may be similar at the BRLJL, where the establishment of a more nocturnal activity can maximize prey capture and reduce water and thermal stress during the hottest period of the year. In periods of milder temperatures, the species may become more active throughout the day, also following a possible increase on the activity of its prey.

Regarding the occurrence of the species inside the studied area, we obtained a relatively high detection rate when compared to studies conducted in other areas of this cat's distribution, as in KASPER et al. (2007), Di BITETTI et al. (2010) and CRUZ et al. (2018) with recording rates lower than 1 per 100 camera-traps. This may be related to the apparent absence of other felid species in the study area, since the studies mentioned above documented the co-occurrence of L. guttulus with other cat species such as margays, ocelots, pumas or jaguars. Besides, the only study we have known to report $L$. guttulus as the only species in the study area, also documented a similar high detection rate (TORTATO \& OliveIRA 2005). In fact, higher relative abundance of L. guttulus was observed in areas with no sympatric cats (Oliveira-SAntos et al., 2012), or where ocelots are less abundant (OliveIra et al., 2010).

The detection of L. guttulus inside the Biological Reserve was not uniformly distributed during the study period; there was a significant increase in the species' detection in August, September, October and November 2018. At least two individuals were identified, a male and a female; the female remained longer in the area than the male, and was detected from July 2018 until at least January 2019. The male was recorded only in four consecutive months (August to November 2018), a period that may be related to the reproductive season. Despite the scarce knowledge of the reproductive periods of small cats in the wild, some observations made in captivity indicate that this species tends to reproduce seasonally in the warmer months of the year (MOREIRA et al., 2001; Morais et al., 2002; ANDREws et al., 2019). The absence of detection of the two individuals identified throughout the study period may be due to home ranges extending beyond the reserve limits, or because these individuals were transient in the area. In fact, BRLJL is a small protected area with only 204 hectares, and despite the few existing data on $L$. guttulus home range, including very variable data $\left(0.9\right.$ to $\left.25 \mathrm{~km}^{2}\right)$, the available mean value $(10.9 \pm$ $9.6 \mathrm{~km}^{2}$ ) easily exceeds the size of the BRLJL (OLIVEIRA et al., 2010).

In conclusion, our study was able to gather information about the ecology of the species that is of great importance, since L. guttulus suffers from a lack of information about its ecological aspects, particularly in the boundaries of its distribution. Our results on the daily activity of this species, along with the existent data on the literature, indicate that it is a very flexible behavioral characteristic of this felid, 
which is able to adjust its activity periods according to the local environmental conditions and the characteristics of the community of which they are part. In addition, our results reported the occurrence of this threatened cat in an important protected area of the State of Rio Grande do Sul. Although conservation units play an important role in protecting biodiversity and threatened species, most Brazilian ones have a huge knowledge gap about their biodiversity and more studies should be carried out in their areas (OliveIRA et al., 2017). Regarding the BRLJL, the most recent data on mammal diversity in this protected area (WITT, 2013) did not document the presence of $L$. guttulus. Despite being a small protected area, not enough to maintain viable populations of this species alone, BRLJL is located in a very urbanized matrix that still maintains important natural remnants from the Pampa and the Atlantic Forest biomes, which can still support populations of endangered species such as small wild felids. The presence of this protected area in this environmental matrix is a guarantee of preservation of the characteristic environments of this region, functioning as an important shelter for several species of native fauna occurring in this area.

Acknowledgments. We are thankful to Biological Reserve Lami José Lutzenberger for allowing us to work in their natural landscape, to Museu de Ciências Naturais do Rio Grande do Sul - SEMA/RS for their infrastructure and research support and to PIBIC/CNPq (Programa Institucional de Bolsas de Iniciação Científica/Conselho Nacional de Desenvolvimento Científico e Tecnológico) for research grant for PL (proc. 103330/2018-6 and 123161/2018-5).

Supplementary material 1. Number of Leopardus guttulus (Hensel, 1872) records in each degree of temperature.

Supplementary material 2. Distribution of the number of records obtained from each of the two individuals of Leopardus guttulus (Hensel, 1872) identified throughout the monitored period in BRLJL, Rio Grande do Sul, Brazil.

\section{REFERENCES}

Agostinelli, C. \& Lund, U. 2017. R package 'circular': Circular Statistics (version 0.4-93). Available at $<$ https://r-forge.r-project.org/ projects/circular/>.

Andrews, C. J.; Thomas, D. G.; Yapura, J. \& Potter, M. A. 2019. Reproductive biology of the 38 extant felid species: a review. Mammal Review 49:16-30.

Balme, G.; Rogan, M.; Thomas, L.; Pitman, R.; Mann, G.; WhittingtonJones, G.; Midlane, N.; BroodryK, M.; BroodryK, K.; Campbell, M.; Alkema, M.; Wright, D. \& Hunter, L. 2019. Big cats at large: Density, structure, and spatio-temporal patterns of a leopard population free of anthropogenic mortality. Population Ecology 61:256-267.

Carrillo, E.; Fuller, T. K. \& SaenZ, J. C. 2009. Jaguar (Panthera onca) hunting activity: effects of prey distribution and availability. Journal of Tropical Ecology 25:563-567.

Cruz, P.; Iezzi, M. E.; De Angelo, C.; Varela, D.; Di Bitetti, M. S. \& PAviolo, A. 2018. Effects of human impacts on habitat use, activity patterns and ecological relationships among medium and small felids of the Atlantic Forest. PLoS ONE 13:1-21.

Di Bitetti, M. S.; de Angelo, C. D.; Di Blanco, Y. E. \& Paviolo, A. 2010. Niche partitioning and species coexistence in a Neotropical felid assemblage. Acta Oecologica 36:403-412.
Dias, D. M.; Massara, R. L.; de Campos, C. B. \& Rodrigues, F. H. G. 2019. Feline predator-prey relationships in a semi-arid biome in Brazil. Journal of Zoology 307:282-291.

Eizirik, E.; Indrusiak, C. B.; Trigo, T. C.; Sana, D. A.; Mazim, F. D. \& Freitas, T. R. O. 2006. Refined mapping and characterization of the geographic contact zone between oncilla and Geoffroy's cat in Southern Brazil. Cat News 25:8-11.

Estado Do Rio Grande Do Sul. 2014. Decreto No $51.797,8$ de setembro de 2014. Declara as espécies da fauna silvestre ameaçadas de extinção no estado do Rio Grande do Sul. Governo do Estado do Rio Grande do Sul, Brazil.

Foster, V. C.; Sarmento, P.; Sollmann, R.; Torres, N.; Jacomo, A. T. A.; Negrões, N.; Fonseca, C. \& Silveira, L. 2013. Jaguar and Puma Activity Patterns and Predator-Prey Interactions in Four Brazilian Biomes. Biotropica 45:373-379.

Gaynor, K. M.; Hojnowski, C. E.; Carter, N. H. \& Brashares, J. S. 2018. The influence of human disturbance on wildlife nocturnality. Science 360:1232-1235.

Harmsen, B. J.; Foster, R. J.; Silver, S. C.; Ostro, L. E. T. \& Doncaster, C. P. 2009. Spatial and temporal interactions of sympatric jaguars (Panthera onca) and pumas (Puma concolor) in a neotropical forest. Journal of Mammalogy 90:612-620.

Harmsen, B. J.; Foster, R. J.; Silver, S. C.; Ostro, L. E. T. \& Doncaster, C. P. 2011. Jaguar and puma activity patterns in relation to their main prey. Mammalian Biology 76:320-324.

Hernández-Saintmartín, D.; Rosas-Rosas, O. C.; Palacio-Núñez, J.; Tarango-Arámbula, L. A.; Clemente-Sánchez, F. \& Hoogesteijn, A. L. 2013. Patrones de actividad del jaguar, puma y sus presas potenciales en San Luis Potosí, México. Acta Zoológica Mexicana 29:520-533.

Horn, P. E.; Pereira, M. J. R.; Trigo, T. C.; Eizirik, E. \& Tirelli, F. P. 2020. Margay (Leopardus wiedii) in the southernmost Atlantic Forest: Density and activity patterns under different levels of anthropogenic disturbance. PLoS ONE 15(5):e0232013.

inMet - Instituto Nacional de Meteorologia. 2018. Dados meteorológico: Estação A801. Porto Alegre, RS, Brasil. Available at $<$ http://www.inmet.gov.br/portal/index.php?r=home/page\&page=rede_ estacoes_auto_graf $>$. Accessed on 15 May 2020.

Kasper, C. B.; Mazim, F. D.; Soares, J. B. G.; Oliveira, T. G. \& Fabián, M. E. 2007. Composição e abundância relativa dos mamíferos de médio e grande porte no Parque Estadual do Turvo, Rio Grande do Sul, Brasil. Revista Brasileira de Zoologia 24(4):1087-1100.

KerR, J. T. 1997. Species Richness, Endemism, and the Choice of Areas for Conservation. Conservation Biology 11:1094-1100.

Kolowski, J. M. \& Alonso, A. 2010. Density and activity patterns of ocelots (Leopardus pardalis) in northern Peru and the impact of oil exploration activities. Biological Conservation 143:917-925.

Leonard, J. P.; Tewes, M. E.; Lombardi, J. V.; Wester, D. W. \& CAmpbell, T. A. 2020. Effects of sun angle, lunar illumination, and diurnal temperature on temporal movement rates of sympatric ocelots and bobcats in South Texas. PLoS ONE 15(4):e0231732.

Macdonald, D. W. \& Loveridge, A. J. 2010. Biology and Conservation of Wild Felids. New York, Oxford University Press. 784p.

MARDIA, K. V. \& JUPP, P. E. 2000. Directional statistics. Chicester, John Wiley \& Sons. 429p.

Marinho, P. H.; Bezerra, D.; Antongiovanni, M.; Fonseca, C. R. \& VenticinQue, E. M. 2018. Activity patterns of the threatened northern tiger cat Leopardus tigrinus and its potential prey in a Brazilian dry tropical forest. Mammalian Biology 89:30-36.

Massara, R. L.; Paschoal, A. M. O.; Bailey, L. L.; Doherty, P. F. JR. \& Chiarello, A. G. 2016. Ecological interaction between ocelots and sympatric mesocarnivores in protected areas of the Atlantic Forest, southeastern Brazil. Journal of Mammalogy 97:1634-1644.

Massara, R. L.; Paschoal, A. M. De O.; Bailey, L. L.; Doherty, P. F.; Barreto, M. De F. \& Chiarello, A. G. 2018. Effect of humans and pumas on the temporal activity of ocelots in protected areas of Atlantic Forest. Mammalian Biology 92:86-93.

MinistÉRIO DO MEIo AMBIENTE. 2018. Livro vermelho da fauna brasileira ameaçada de extinção. Brasília, ICMBio/MMA, v. I. 492p. 
Monterroso, P.; Alves, P. C. \& Ferreras, P. 2014. Plasticity in circadian activity patterns of mesocarnivores in Southwestern Europe: implications for species coexistence. Behavioral Ecology and Sociobiology 68:1403-1417.

Morais, R. N.; Mucciolo, R. G.; Gomes, M. L. F.; Lacerda, O.; Moraes, W.; Moreira, N.; Graham, L. H.; Swanson, W. F. \& Brown, J. L. 2002. Seasonal analysis of semen characteristics, serum testosterone and fecal androgens in the ocelot (Leopardus pardalis), margay ( $L$. wiedii) and tigrina (L. tigrinus). Theriogenology 57(8):2027-2041.

Moreira, N.; Monteiro-Filho, E. L. A.; Moraes, W.; Swanson, W. F.; Graham, L. H.; Pasquali, O. L.; Gomes, M. L. F.; Morais, R. N.; WiLdT, D. E. \& Brown, J. L. 2001. Reproductive steroid hormones and ovarian activity in felids of the Leopardus genus. Zoo Biology 20:103-116.

Nagy-Reis, M. B.; Iwakami, V. H. S.; Estevo, C. A. \& Setz, E. Z. F. 2019. Temporal and dietary segregation in a neotropical small-felid assemblage and its relation to prey activity. Mammalian Biology 95:1-8.

Nascimento, F. O. Do \& FeiJó, A. 2017. Taxonomic revision of the tigrina Leopardus tigrinus (Schreber, 1775) species group (Carnivora, Felidae). Papéis Avulsos de Zoologia 57:231-264.

Nix, J. H.; Howell, R. G.; Hall, L. K. \& McMillan, B. R. 2018. The influence of periodic increases of human activity on crepuscular and nocturnal mammals: Testing the weekend effect. Behavioural Processes 146: $16-21$.

Oliveira, T. G. \& Cassaro, E. K. 2005. Guia de Campo dos Felinos do Brasil. Instituto Pró-Carnívoros/Fundação Parque Zoológico de São Paulo/Sociedade de Zoológicos do Brasil/ Pró-Vida Brasil, São Paulo. 80p.

Oliveira, T. G.; Tortato, M. A.; Silveira, L.; Kasper, C. B.; Mazim, F. D.; Lucherini, M.; Jácomo, A. T.; Soares, J. B. G.; Marques, R. V. \& SunQuisT, M. 2010. Ocelot ecology and its effect in the small-felid guild in the lowland Neotropics. In: Macdonald, D. W. \& Loveridge, A. eds. Biology and Conservation of Wild Felids. Oxford, Oxford University Press, p. 559-580.

Oliveira, T. G.; Trigo, T.; Tortato, M.; Paviolo, A.; Bianchi, R. \& LeitePitman, M. R. P. 2016. Leopardus guttulus. The IUCN Red List of Threatened Species 2016:e.T54010476A54010576.

Oliveira, U.; Soares-Filho, B. S.; Pagila, A. P.; Brescovit, A. D.; DE Carvalho, C. J. B.; Silva, D. P.; Rezende, D. T.; Leite, F. S. F.; Batista, J. A. N.; Barbosa, J. P. P. P.; Stehmann, J. R.; Ascher, J. S.; de Vasconcelos, M. F.; de Marco, P.; LöWenberg-Neto, P.; Ferro, V. G. \& Santos, A. J. 2017. Biodiversity conservation gaps in the Brazilian protected areas. Scientific Reports 7:9141.

Oliveira-Santos, L. G. R.; Graipel, M. E.; Tortato, M. A.; Zucco, C. A.; Cáceres, N. C. \& Goulart, F. V. B. 2012. Abundance changes and activity flexibility of the oncilla, Leopardus tigrinus (Carnivora: Felidae), appear to reflect avoidance of conflict. Zoologia 29(2):115120.

Penido, G.; Astete, S.; Jácomo, A. T. A.; Sollmann, R.; Tôrres, N.; SilveIrA, L. \& MARINHO FilHO, J. 2017. Mesocarnivore activity patterns in the semiarid Caatinga: limited by the harsh environment or affected by interspecifc interactions? Journal of Mammalogy 98:1732-1740.

Podolski, I.; Belotti, E.; BufKa, L.; Reulen, H. \& Heurich, M. 2013. Seasonal and daily activity patterns of free-living Eurasian lynx Lynx lynx in relation to availability of kills. Wildlife Biology 19:69-77.

Porfirio, G.; Foster, V. C.; Fonseca, C. \& Sarmento, P. 2016. Activity patterns of ocelots and their potential prey in the Brazilian Pantanal. Mammalian Biology 81(5):511-517.

Printes, R. C. 2002. Plano de Manejo Participativo da Reserva Biológica do Lami. Porto Alegre, SMAM. 102p.

Rafiq, K.; Hayward, M. W.; Wilson, A. M.; Meloro, C.; Jordan, N. R.; Wich, S. A.; McNutt, J. W. \& GolabeK, K. A. 2020. Spatial and temporal overlaps between leopards (Panthera pardus) and their competitors in the African large predator guild. Journal of Zoology 311:246-259.

R Core TeAm. 2020. R: A language and environment for statistical computing. R Foundation for Statistical Computing, Vienna, Austria. Available at <https://www.R-project.org/>.

Ridout, M. \& Linkie, M. 2009. Package 'overlap': Estimates of Coefficient of Overlapping for Animal Activity.

Romero-Muñoz, A.; MAFFeI, L.; CuÉllar, E. \& Noss, A. J. 2010. Temporal separation between jaguar and puma in the dry forests of southern Bolivia. Journal of Tropical Ecology 26:303-311.

Sartor, C. C.; Cushman, S. A.; Wan, H. Y; Kretschmer, R.; Pereira, J. A.; Bou, N.; Cosse, M.; GonzÁlez, S.; EizIrik, E.; Freitas, T. R. O. \& Trigo, T. C. 2021. The role of the environment in the spatial dynamics of an extensive hybrid zone between two Neotropical cats. Journal of Evolutionary Biology, early view. https://doi.org/10.1111/jeb.13761

Torretta, E.; Serafini, M.; Puopolo, F. \& Schenone, L. 2016. Spatial and temporal adjustments allowing the coexistence among carnivores in Liguria (N-W Italy). Acta Ethologica 19:123-132.

Tortato, M. A. \& Oliveira, T. G. 2005. Ecology of the oncilla (Leopardus tigrinus) at Serra do Tabuleiro State Park, Southern Brazil. Cat News 42:28-30.

Trigo, T. C.; Schneider, A.; Oliveira, T. G.; Lehugeur, L. M.; Silveira, L.; Freitas, T. R. O. \& EiziriK, E. 2013a. Molecular Data Reveal Complex Hybridization and a Cryptic Species of Neotropical Wild Cat. Current Biology 23:2528-2533.

Trigo, T. C.; Fontoura-Rodrigues, M. L. \& Kasper, C. B. 2013 b. Carnívoros continentais. In: Weber, M. M.; Roman, C. \& CÁceres, N. C. orgs. Mamíferos do Rio Grande do Sul. Santa Maria, Editora UFSM, p. 362-363.

Witt, P. B. R. 2013. Fauna e Flora da Reserva Biológica do Lami José Lutzenberger. 1ed. Porto Alegre, Secretaria Municipal do Meio Ambiente. 308p.

ZhaO, G.; YANG, H.; XIE, B.; Gong, Y.; Ge, J. \& FenG, L. 2020. Spatiotemporal coexistence of sympatric mesocarnivores with a single apex carnivore in a fine-scale landscape. Global Ecology and Conservation 21:e00897. 